DOI 10.15276/imms.v9.no3.158

Informatics and Mathematical Methods in Simulation

УДК 004.056.5

Vol. 9 (2019), No. 3, pp. 158-167

\title{
HISTOGRAM ANALYSIS FOR DETECTION OF SHARPENED DIGITAL IMAGES
}

\author{
V.V. Zorilo ${ }^{1}$, O.V. Pyvovar ${ }^{1}$, P.S. Safronov ${ }^{1}$, O.Yu. Lebedieva ${ }^{1}$, M.E. Shelest ${ }^{2}$
}

\author{
${ }^{1}$ Odessa National Polytechnic University, \\ 1, Shevchenko Ave., Odessa, 65044, Ukraine; e-mail: vikazorilo@gmail.com \\ ${ }^{2}$ National University «Chernihiv Polytechnic», \\ 95, Shevchenko Str., Chernihiv, 14000, Ukraine; e-mail: mishel3141@ gmail.com
}

\begin{abstract}
The information technologies are spreading in the modern world and are one or more interconnected software products for a particular computer that helps the user achieve this aim. Every day we receive a wealth of digital information, such as emails, articles on the Internet, messages in various communication systems, and more. Therefore, the issue of qualitative and rapid verification of its authenticity, namely, elements such as digital images, is very timeliness. Digital images are often not original. They have different types of integrity violations, such as cloning or collage. After applying these operations, the different filters for blurring, brightness and contrast variation, sharpening, etc. often are used to hide the digital image processing. These operations are performed by graphic editors such as GIMP. In this graphic editor, which is a free analogue to the Adobe Photoshop graphic editor, sharpening is implemented as an Unsharp Mask Filter. A review of open source literature has shown that little attention is paid to detecting artificial sharpening. From open sources it is known about the method for detection of artificial sharpening based on the analysis of close color pairs of the image matrix. Its main disadvantage is the high number of the type I errors and the type II errors. This fact leads to the development of new methods and algorithms for detection this type of image processing. The object of this work is to detect artificial sharpening of a digital image as an integrity violation. A study is conducted in which the formal parameters of the digital image matrix were revealed, indicating the presence of artificial sharpening. A quantitative estimation of the qualitative differences between processed and raw images is obtained and used as a threshold for detecting artificially sharpened images. An algorithm for the detection of the artificial sharpening of a digital image is developed and its efficiency is estimated, According to this algorithm, the number of the type I errors is $3,8 \%$, and the number of the type II errors is $9,8 \%$. The development potential of this work is to improve the detection of different ways of artificial sharpening the digital image.
\end{abstract}

Keywords: sharpening detection, digital image, integrity violations, information protection, Unsharp Mask Filter, sharpness factor, histogram peak

\section{Introduction}

In today's fast-paced technology world, when almost everyone has their own computer, the number of different applications, including applications for the image processing, is grown dramatically. As a result of growing competition in the software market, in an effort to pay attention to their product, developers make them as cheap as possible, and even completely free of charge. As a result, image processing tools become available to any user of a personal computer or smart phone. But this availability of the processing tools has contributed to the rise of cybercrime. Using photo editors is not uncommon today. The most common image processing is used to remove any shortcomings digital image (DI). However, this may also indicate an attempt to conceal the forgery. By the widely available Internet, spreading false information is extremely easy and fast. As a result, the facts may be distorted, and this may affect public opinion, which will have a negative social impact. The consequences can be even worse, especially in justice, when photos are presented as evidence [1]. 
There are many such situations, which is not surprising given that access to the DI is open and the number of situations caused by false information obtained through the DI increases every second. Based on that, manipulation of the visible surface of the image or invisible parts is performed, manipulation methods can be classified as the forged image or the steganographic image. The damage to the image can be done either by modifying the context of the scene elements, or without modifying the context. Otherwise, the journalist deceives the opinion that the objects of the image are something else from what they really are, but the image itself does not change.

Fig. 1 shows an image published in November 1997 after 58 tourists were killed in a terrorist attack at the Hatshepsut Temple in Luxor, in which a puddle of water has been digitally altered to make it look like blood flowing from a temple [2].

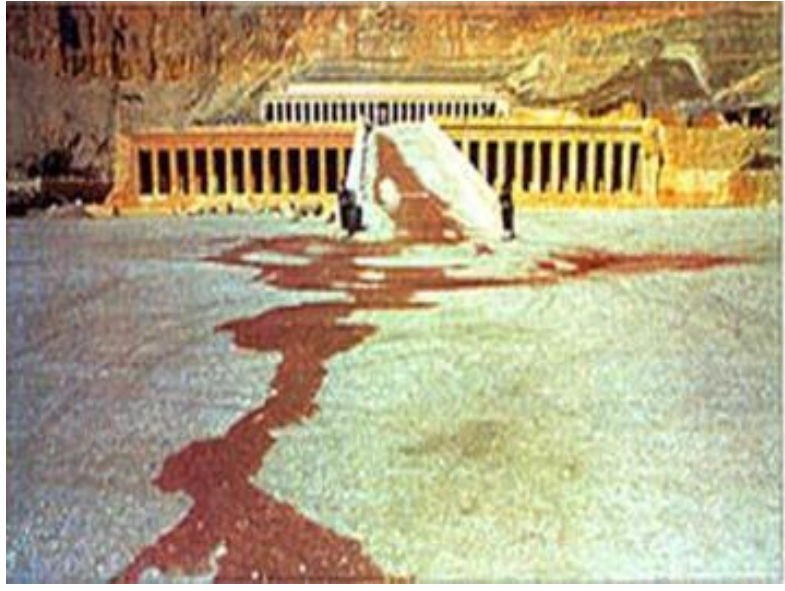

a

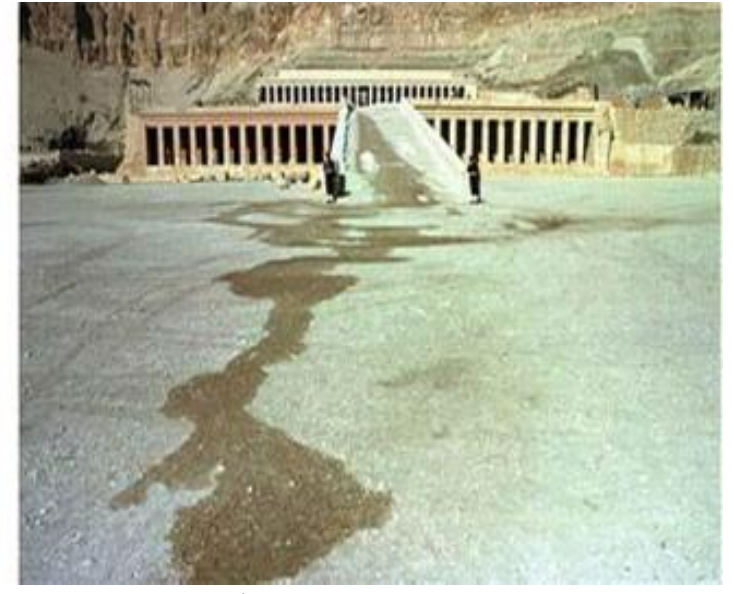

b

Fig. 1. Photo of the Temple of Hatshepsut after the terrorist attack: $a$ - forged image; $b$ - the original image

Thus there is a high demand for a valid and reliable authentication method to distinguish whether the picture is original or not. Sharpening is one of the most common ways to process forged DI. However, despite the popularity of this filter not much is known about the methods for the sharpening detection.

A method for detection image processing by sharpening filter is published in [3].

A blur detection method is based on the analysis of the growth rate of the corresponding singular values. The threshold value for the growth rate of singular values is determined. In case of exceeding the threshold value, it is concluded that the images is not blurred, otherwise the images is considered blurred. In this situation, though, using sharpness increases the growth rate of the singular values, but it is impossible to set a threshold value, since different images will be characterized by different sharpness and different growth rate of the singular values, respectively.

The technical journal Informatics and Mathematical Methods in Simulation (\# 2, 2018) discusses an improved method for sharpening detection.

The method is based on the analysis of close color pairs with respect to the total number of color pairs of digital image matrices. The difference between these values is currently large enough to distinguish a threshold value that allows distinguishing the processed image from the raw one, but it is necessary to find ways to increase the difference between these values to reduce the number of errors in the method [4].

The ability to separate the true image from the artificially sharpened image will increase the efficiency of the complex system of information protection. The methods covered by publications today have proved to be ineffective in detecting sharpness due to the large number of the type I errors and the type II errors. It is not possible therefore to clearly identify 
a method that allows the separation of images processed by the sharpness filter from the raw ones.

\section{The aim of the paper} violation.

The aim of this work is to identify artificial sharpening the digital images as an integrity

In order to achieve this aim, it is necessary to solve the following problems:

- identifying the formal parameters of the DI matrix indicating the presence of artificial sharpening;

- obtaining a quantitative estimation of the qualitative differences between the obtained parameters when the first problem is solved; a quantitative estimation can be used as a threshold value to separate the processed DI from the original ones;

- developing an algorithm for detecting artificial sharpening of DI and evaluating its effectiveness.

\section{Main Part}

As DI processing medium, GIMP is selected because it is one of the most popular free image editors. GIMP is an example of the embodiment of the simple idea of Peter Mattis which is to create a graphic application for DI processing (similar to Adobe Photoshop). GIMP is designed to provide an intuitive graphical user interface for a variety of the image editing operations [5].

Today, GIMP is a cross-platform graphic image editor that works with raster graphics, but also partially supports the vector ones and is available for GNU/Linux, OS X, Windows, and other operating systems. It is free software where anyone can modify its code and distribute modification [6].

In order to sharpening the image, the Unsharp Mask Filter is used. The Unsharp Mask Filter makes clearer edges of the elements without increasing the noise and without disturbing the visual perception stability. Therefore, it is one of the best sharpening filters.

To examine the image for post processing, histograms of each color component of the DI represented in the RGB color model are considered. Histogram is bar grah of the image halftone distribution in which brightness is represented on the horizontal axis, and the number of pixels of the image block with brightness values is represented on vertical axis.

By examining 700 images of different types, we were able to identify some regularities in the histograms of the color components of the DI.

As a result, examining of the histogram of the B color component (RGB image) revealed a noticeable increase in the number of pixels whose brightness value is 0 (Fig. 2).
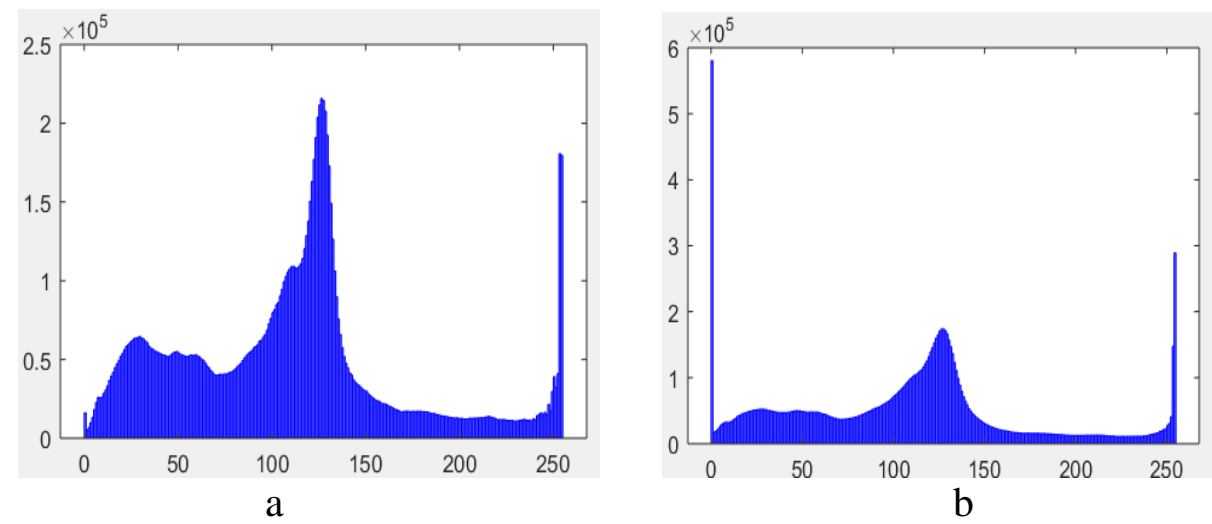

Fig. 2. Histogram of the B component: $a$ - before processing; $b$ - after processing 
The increase in pixels with zero brightness after filter processing increased significantly, but the increase in black was noticeable before processing. Therefore, the histogram of the $G$ component (Fig. 3) should be considered further.
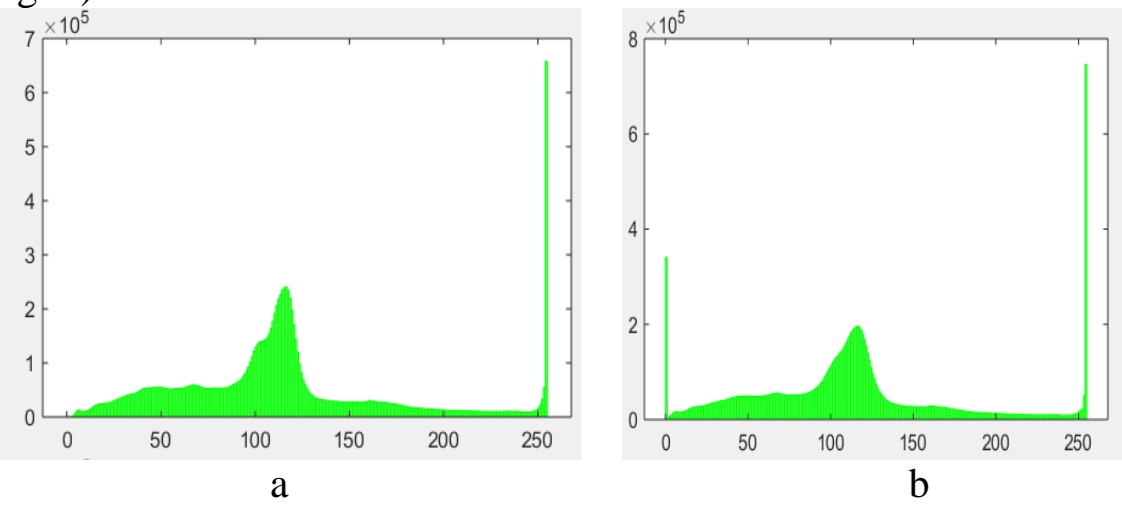

Fig. 3. Histogram of the $\mathrm{G}$ component: $\mathrm{a}$ - before processing; $\mathrm{b}$ - after processing

The histogram of this component also showed a noticeable increase in pixels with zero brightness. However, unlike the results obtained from the B component, there is no increase in black values on the original $\mathrm{G}$ channel, but it has appeared after processing. In order to obtain a complete estimate of the deformation of the color components of the DI after processing, the $\mathrm{R}$ histogram is examined.

The result of the study of the histogram of the $\mathrm{R}$ component is the increase of zero pixels of this component also (Fig. 4).
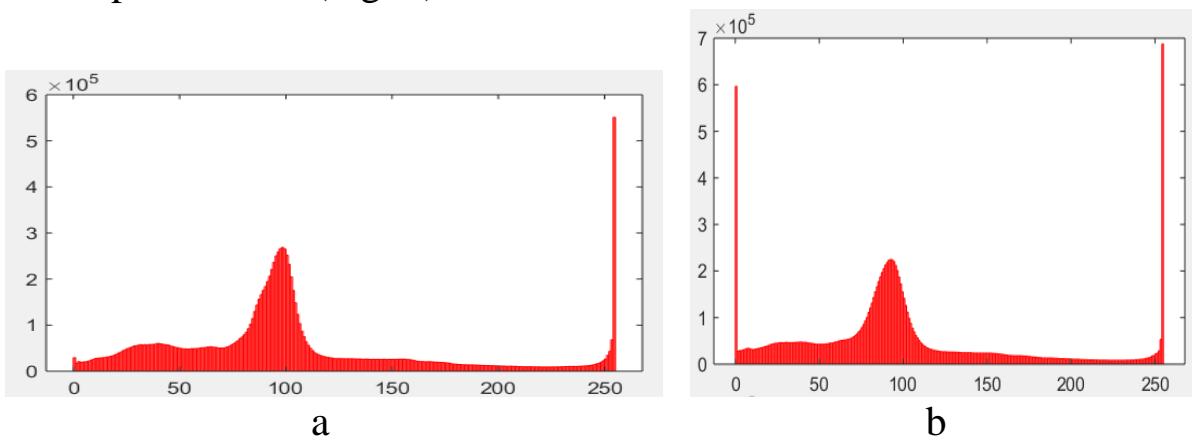

Fig. 4. Histogram of the $\mathrm{G}$ component: $\mathrm{a}$ - before processing; $\mathrm{b}$ - after processing

Fig. 5 shows the histograms of all three color components at once.

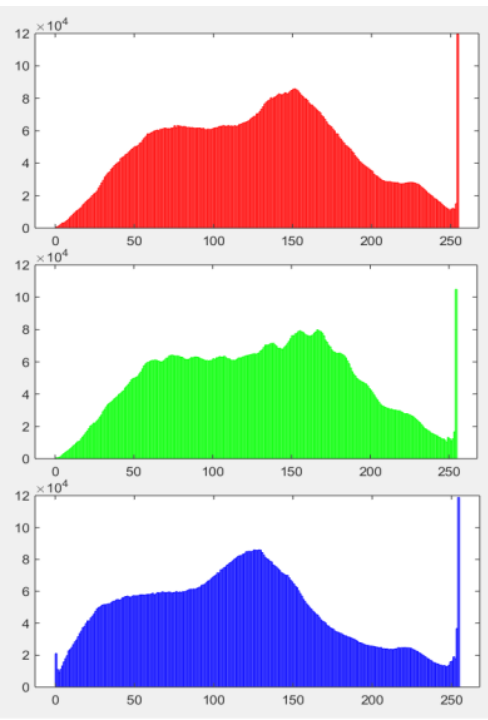

a

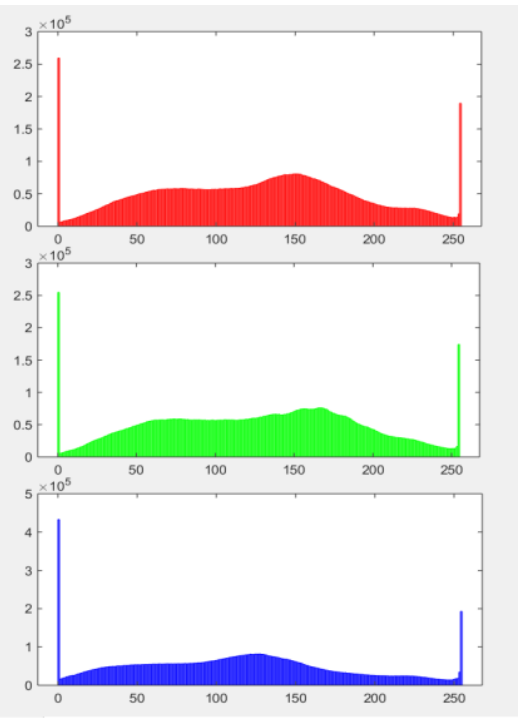

b

Fig. 5. Histogram of the RGB color components: $a$ - before processing; $b$ - after processing 
Generally speaking, it can be argued that using the Unsharp Mask Filter for the image affects all three RGB components of the DI simultaneously. On this basis, it is further advisable to consider the histograms of all three color components at once.

As a result of the joint examination of the histograms of the RGB component of the other DI, it becomes apparent that after the processing of the DI by the filter, there is a significant increase in the amount of black in all components simultaneously. Such an increase in black will be referred to as the black peak. Although such peaks appear in the DI after processing, they can also be present in the components of the original image. Therefore, it is worth examining this feature on a larger number of the DIs for a complete estimation. The results are (partially) presented in Table 1.

Results of finding black peaks in the DI

Table 1.

\begin{tabular}{c|c|c|c|c|c|c}
\hline \multirow{2}{*}{$\#$} & \multicolumn{3}{|c|}{ Before processing } & \multicolumn{3}{c}{ After processing } \\
\cline { 2 - 7 }$\#$ & Red & Green & Blue & Red & Green & Blue \\
\hline 1 & - & - & + & + & + & + \\
\hline 2 & + & + & + & + & + & + \\
\hline 3 & - & + & + & + & + & + \\
\hline 4 & - & + & + & + & + & + \\
\hline 5 & - & - & + & + & + & + \\
\hline 6 & + & - & + & + & + & + \\
\hline 7 & - & - & + & + & + & + \\
\hline 8 & - & - & + & + & + & + \\
\hline 9 & - & - & + & + & + \\
\hline 10 & - & + & + & + & + \\
\hline
\end{tabular}

If the black peak is found, the symbol " $+"$ is entered in the table, but if there is no increase in black then symbol "-" is entered in the table.

As a result of the experiment, it becomes apparent that in the vast majority of images, peaks appear in one or two color components or are absent in any. After processing the digital images by the Unsharp Mask Filter, the peaks appear in all three histograms of the color components, thanks to this feature and we will construct an algorithm. However, for sufficiently contrasting images, the increase of zero values may also be noticeable before processing.

It should be noted that in some cases it is quite difficult to visually estimate the increase of black in the histograms due to the different filling of the color components in different DIs. Therefore, referring to the histograms in Fig. 5, it should be noted that the peaks relative to other close values of the brightness of the considerate component, due to the application of the sharpness filter, become similar in all three components.

This uniformity is caused by the uniform processing of each of the RGB components and has not yet occurred in the original image. Based on this, we will only estimate the peak. But we will give an estimate as a percentage, since the quantitative filling of the brightness values of each component is very individual and depends on many criteria of the DI itself, such as priority in color interpolation, illumination, CCD matrix, etc.

Let R, G, and B be the matrices of the red, green, and blue components of the digital image, $\left(r_{i j}, g_{i j}, b_{i j}\right)$ is the triad of digital pixel components with coordinates $(i, j)$. Using these 
notations, we will construct an algorithm for sharpening detection:

Step 1. For the $R$ matrix, $r$ equal to the number of $\left(0, g_{i j}, b_{i j}\right)$ triads and $r^{\prime}$ equal to the number of $\left(1, g_{i j}, b_{i j}\right)$ triads are found.

If $r=0$,

then it is considered the image is not processed by the Unsharp Mask Filter,

otherwise go to Step 2.

Step 2. For the matrix $G, g$ equal to the number of $\left(r_{i j}, 0, b_{i j}\right)$ triads and $g^{\prime}$ equal to the number of $\left(r_{i j}, 1, b_{i j}\right)$ triads are found.

If $g=0$,

then it is considered the image is not processed by the Unsharp Mask Filter,

otherwise go to Step 3.

Step 3. For matrix $B, b$ equal to the number of $\left(r_{i j}, g_{i j}, 0\right)$ triads and $b^{\prime}$ equal to the number of $\left(r_{i j}, g_{i j}, 1\right)$ triads are found.

If $r=0$,

then it is considered the image is not processed by the Unsharp Mask Filter,

otherwise go to Step 4.

Step 4. If $r<r^{\prime}$ або $g<g^{\prime}$ aбо $b<b^{\prime}$,

then it is considered the image is not processed by the Unsharp Mask Filter,

otherwise go to Step 5.

Step 5. The sharpness factor K is obtained according to the formula (2.1) by calculating previously the percentage of the difference of the triads $r$ and $r$ ' for the red component $r R$ by the formula (2.2), similarly the percentage of the difference of the triads $\mathrm{g}$ and $\mathrm{g}^{\prime}$ for the green component $\mathrm{rG}$ by the formula (2.3) and the percentage of the difference of the triads $\mathrm{b}$ and $\mathrm{b}^{\prime}$ for the blue component $r B$ by the formula (2.4):

$$
K=\frac{|r R-r G|+|r G-r B|+|r B-r R|}{3},
$$

wherein

$$
\begin{aligned}
& r R=\frac{\left(r-r^{\prime}\right) * 100}{r}, \\
& r G=\frac{\left(g-g^{\prime}\right) * 100}{g}, \\
& r B=\frac{\left(b-b^{\prime}\right) * 100}{b} .
\end{aligned}
$$

Step 6. If $K<16$,

then it is considered the image is processed by the Unsharp Mask Filter, otherwise the image is original.

\section{Results and Discussion}

In Table 2, it can be observed the results of the study in the DIs before processing by the Unsharp Mask Filter.

As can be seen from the results presented in these two tables, the desired sharpness factor of the DI after the application of the specified filter is significantly reduced compared to the same characteristic before processing the digital image. This feature makes it possible to detect the integrity violation of the image by artificially sharpening. 
Results of the study in the DIs before processing

Table 2.

Before processing

\begin{tabular}{c|c|c|c|c|c|c|c}
\hline DI \# & rR & rG & rB & $\mid$ rR-rG $\mid$ & $|\mathrm{rG}-\mathrm{rB}|$ & $|\mathrm{rB}-\mathrm{rR}|$ & $\mathrm{K}$ \\
\hline 1 & 59.61401 & 46.18474 & 82.5343 & 13.42927 & 36.34956 & 22.92029 & 24.23304 \\
\hline 2 & 24.10318 & 54.27052 & 74.43302 & 30.16735 & 20.16249 & 50.32984 & 33.55323 \\
\hline 3 & 37.92185 & 59.46909 & 82.9935 & 21.54724 & 23.52441 & 45.07165 & 30.04777 \\
\hline 4 & 41.5703 & 49.04473 & 79.13701 & 7.474431 & 30.09228 & 37.56671 & 25.04448 \\
\hline 5 & 0 & 25.10154 & 83.7167 & 25.10154 & 58.61516 & 83.7167 & 55.81113 \\
\hline 6 & 48.54641 & 0 & 80.12792 & 48.54641 & 80.12792 & 31.58151 & 53.41861 \\
\hline 7 & 53.02198 & 1.935484 & 87.22527 & 51.08649 & 85.28979 & 34.2033 & 56.85986 \\
\hline 8 & 0 & 0 & 47.77889 & 0 & 47.77889 & 47.77889 & 31.85259 \\
\hline 9 & 0 & 41.89189 & 55.90361 & 41.89189 & 14.01172 & 55.90361 & 37.26908 \\
\hline 10 & 47.31138 & 57.60901 & 84.12761 & 10.29763 & 26.5186 & 36.81623 & 24.54415 \\
\hline
\end{tabular}

Table 3 shows the results of the study in the same DIs after processing by the Unsharp Mask Filter.

Table 3.

Results of the study in the DIs after processing

\begin{tabular}{c|c|c|c|c|c|c|c}
\hline \multicolumn{7}{c}{ After processing } \\
\hline DI \# & rR & rG & rB & $\mid$ rR-rG $\mid$ & $\mid$ rG-rB $\mid$ & $\mid$ rB-rR $\mid$ & K \\
\hline 1 & 98.69817 & 98.48332 & 95.83575 & 0.214851 & 2.86242 & 2.64757 & 1.90828 \\
\hline 2 & 98.59418 & 98.55068 & 98.48153 & 0.043497 & 0.069148 & 0.112645 & 0.075096 \\
\hline 3 & 97.8734 & 97.90032 & 97.16821 & 0.026917 & 0.732104 & 0.705188 & 0.488069 \\
\hline 4 & 97.0169 & 97.10855 & 96.08312 & 0.091656 & 1.025433 & 0.933777 & 0.683622 \\
\hline 5 & 98.82973 & 98.81233 & 98.48181 & 0.017402 & 0.330515 & 0.347917 & 0.231944 \\
\hline 6 & 99.33043 & 99.34721 & 99.30064 & 0.016777 & 0.046571 & 0.029794 & 0.031047 \\
\hline 7 & 99.0403 & 98.99713 & 98.9642 & 0.043163 & 0.032937 & 0.076101 & 0.050734 \\
\hline 8 & 97.64324 & 97.85388 & 96.28881 & 0.210643 & 1.56507 & 1.354427 & 1.04338 \\
\hline 9 & 94.80096 & 93.9693 & 94.61643 & 0.831664 & 0.647135 & 0.184529 & 0.554442 \\
\hline 10 & 98.73552 & 98.75984 & 98.35214 & 0.024321 & 0.407695 & 0.383375 & 0.271797 \\
\hline
\end{tabular}

The experiment to determine the algorithm effectiveness is carried out. For its implementation, it is used 500 own images obtained with a smartphone and 200 images obtained with modern digital cameras (owned by NRCS). The digital images after application of artificial sharpening filter (Unsharp Mask Filter) are stored in a lossless format in the graphic editor GIMP. The GIMP editor is multifunctional. It can be used as a simple graphic editor, as a professional photo retouching application, as a network batch image processing system, as an image playback program, as an image format converter, etc.

The digital images of lossless formats (*.TIF, *.BMP, *.PNG) is taken according to the GIMP quality standard. The images used for the experiment are arbitrary in size. The efficiency of the developed algorithm is estimated in terms of type I and type II errors. 
The type I errors mean incorrectly rejected the application of the filter; the type II errors mean the case when the raw DI is mistaken for the processed one. Table 4 shows the results of the analysis.

Table 4.

Analysis of the algorithm effectiveness

\begin{tabular}{c|c|c}
\hline & Type I errors & Type II errors \\
\hline The original image & - & $9.8 \%$ \\
\hline $\begin{array}{c}\text { The image processed by the Unsharp } \\
\text { Mask Filter }\end{array}$ & $3.8 \%$ & - \\
\hline
\end{tabular}

According to the results of the study, the following conclusions can be drawn. The developed algorithm has high efficiency. This algorithm also has the applicability restrictions. Firstly, it is only tested for the particular filter in the particular graphic editor. Secondly, studies are not carried out with saving the processed DI in the lossy format.

However, all these disadvantages can be the subject of further development of this work, as well as adjusting the formula to detect the application of the Unsharp Mask Filter in the image in order to reduce the number of the type I errors and the number of the type II errors.

\section{Conclusions}

It has been established that the DI post-processing as a DI forging has been given insufficient attention, in particular to the detection of artificial sharpening of the digital image. Methods known from open sources have a large number of the type I errors and the type II errors, so other methods for detection of the DI post-processing by this filter should be developed.

The parameters of quantitative estimation of qualitative differences between the processed digital images and the original ones have been revealed.

Based on these parameters, a threshold value is selected to distinguish the processed images from the raw ones.

The algorithm for detection of the artificial sharpening of a digital image is developed and implemented into sofware.

The efficiency of this algorithm is estimated, according to which the number of the type I errors is $3.8 \%$, and the number of the type II errors is $9.8 \%$.

\section{References}

1. The Scientific World Journal. Research Article. Digital Image Forgery Detection Using JPEG Features and Local Noise Discrepancies [Електронний pecypc] // Режим доступу: World Wide Web. - URL: https://www.hindawi.com/journals/tswj/2014/230425/ (дата звернення 19.03.2019)

2. International journal of computer science and business informatics [Електронний ресурс] // Режим доступу до ресурсу: World Wide Web. - URL: http://ijcsbi.org/ijcsbi/index.php/ijcsbi/article/view/50 (дата звернення 18.03.2019).

3. Зорило, В.В. Исследование влияния повышения резкости на математические параметры цифрового изображения для выявления фотомонтажа [Електронний ресурс] / В.В. Зорило, Е.Ю. Лебедева, А.И. Матвеева, А.А. Ефименко, В.А. Мокрицкий // Режим доступу до pecypcy: World Wide Web. - URL: http://suchasnaspetstehnika.com/index_html_files/SST-20172,\%201-114_.pdf (дата звернення 20.03.2019).

4. Зоріло, В.В. Модифікація алгоритму виявлення штучного підвищення різкості цифрового зображення / В.В. Зоріло, О.І. Кіосєва, І.В. Зоріло // Інформатика та математичні методи в моделюванні. - Т.8, №2. - 2018. - С.48-55. 
5. How It All Started [Електронний ресурс] // Режим доступу до ресурсу: World Wide Web. URL: https://www.gimp.org/about/prehistory.html (дата звернення 18.03.2019).

6. The Free \& Open Source Image Editor [Електронний ресурс] // Режим доступу до ресурсу: World Wide Web. - URL: https://www.gimp.org/ (дата звернення 18.03.2019).

\section{АНАЛІЗ ГИСТОГРАМ У ВИЯВЛЕННІ ПІДВИЩЕННЯ РІЗКОСТІ ЦИФРОВОГО ЗОБРАЖЕННЯ}

В.В. Зоріло ${ }^{1}$, О.В. Пивовар ${ }^{1}$, П.С. Сафронов ${ }^{1}$, О.Ю. Лебедєва ${ }^{1}$, М.Є. Шелест ${ }^{2}$

${ }^{1}$ Одеський національний політехнічний університет, просп. Шевченка, 1, Одеса, 65044, Україна; e-mail: vikazorilo@ gmail.com

${ }^{2}$ Національний університет «Чернігівська політехніка», вул. Шевченка, 95, Чернігів, 14000, Україна; e-mail: mishel3141@ gmail.com

Інформаційні технології невідступно поширюються в сучасному світі і являють один або декілька взаємопов'язаних програмних продуктів для певного комп'ютера, за допомогою яких користувач досягає поставленої мети. Кожного дня ми отримуємо велику кількість цифрової інформації, такої як повідомлення електронною поштою, статті в мережі Інтернет, повідомлення в різних системах спілкування та інше. Тому дуже актуальним постає питання якісної та швидкої перевірки ії достовірності, а саме, таких елементів як цифрові зображення. Цифрові зображення часто не $\epsilon$ оригінальними. В них мають місце різні типи порушення цілісності, наприклад, клонування або колаж. Після застосування даних операцій часто використовують різні фільтри для маскування - розмиття, зміна яскравості, контрастності, підвищення різкості тощо. Дані операції виконують засобами графічних редакторів, наприклад, GIMP. В даному графічному редакторі, який є безкоштовним аналогом графічного редактору Adobe Photoshop, підвищення різкості реалізовано у вигляді фільтру «Unsharp Mask». Огляд літератури, доступної з відкритих джерел, показав, що виявленню штучного підвищення різкості приділяється дуже мало уваги. 3 відкритого друку відомо про метод виявлення штучного підвищення різкості, заснований на аналізі близьких пар кольорів матриці зображення. Головний його недолік - висока кількість помилок 1 та 2 роду. Цей факт спонукає до розробки нових методів та алгоритмів виявлення даного виду обробки зображення. Мета даної роботи - виявлення штучного підвищення різкості цифрового зображення як порушення його цілісності. Проведено дослідження, в ході якого виявлено формальні параметри матриці цифрового зображення, що вказують на наявність штучного підвищення різкості. Отримано кількісну оцінку якісних відмінностей оброблених та необроблених зображень, котрі використано як порогове значення для виявлення зображень зі штучно підвищеною різкістю. Розроблено алгоритм виявлення штучного підвищення різкості цифрового зображення та проведено оцінку його ефективності, згідно якої кількість помилок 1 роду складає $-3,8 \%$, помилки 2 роду $9,8 \%$. Перспективи подальшого розвитку даної роботи полягають у вдосконаленні виявлення різних способів штучного підвищення різкості цифрового зображення.

Ключові слова: виявлення підвищення різкості, цифрове зображення, порушення цілісності, захист інформації, фільтр «unsharp mask», коефіцієнт різкості, пік гістограми. 


\title{
АНАЛИЗ ГІСТОГРАМ В ВЫЯВЛЕНИИ ПОВЫШЕНИЯ РЕЗКОСТИ ЦИФРОВОГО ИЗОБРАЖЕНИЯ
}

\author{
В.В. Зорило ${ }^{1}$, О.В. Пивовар ${ }^{1}$, П.С. Сафронов ${ }^{1}$, Е.Ю. Лебедева ${ }^{1}$, М.Е. Шелест ${ }^{2}$
}

Одесский национальный политехнический университет,

просп. Шевченко, 1, Одесса, 65044, Украина; e-mail: vikazorilo@gmail.com

${ }^{2}$ Национальный университет «Черниговская политехника»,

ул. Шевченко, 95, Чернигов, 14000, Украина; e-mail: mishel3141@gmail.com

Информационные технологии постоянно распространяются в современном мире и представляют один или несколько взаимосвязанных программных продуктов для определенного компьютера, с помощью которых пользователь достигает поставленной цели. Каждый день мы получаем большое количество цифровой информации, такой как сообщение по электронной почте, статьи в сети Интернет, сообщения в различных системах общения и прочее. Поэтому очень актуальным становится вопрос качественной и быстрой проверки ее достоверности, а именно, таких элементов как цифровые изображения. Цифровые изображения часто являются оригинальными. В них имеют место различные типы нарушения целостности, например, клонирование или коллаж. После применения данных операций часто используют различные фильтры для маскировки - размытие, изменение яркости, контрастности, повышение резкости и тому подобное. Данные операции выполняют средствами графических редакторов, например, GIMP. В данном графическом редакторе, который является бесплатным аналогом графического редактора Adobe Photoshop, повышение резкости реализовано в виде фильтра «Unsharp Mask». Обзор литературы, доступной из открытых источников, показал, что выявлению искусственного повышения резкости уделяется очень мало внимания. Из открытого печати известно о методе выявления искусственного повышения резкости, основанный на анализе близких пар цветов матрицы изображения. Главный его недостаток - высокая количество ошибок 1 и 2 рода. Этот факт побуждает к разработке новых методов и алгоритмов обнаружения данного вида обработки изображения. Цель данной работы - выявление искусственного повышения резкости цифрового изображения как нарушение его целостности. Проведено исследование, в ходе которого выявлено формальные параметры матрицы цифрового изображения, указывающие на наличие искусственного повышения резкости. Получено количественную оценку качественных различий обработанных и необработанных изображений, которые использованы как пороговое значение для выявления изображений с искусственно повышенной резкостью. Разработан алгоритм выявления искусственного повышения резкости цифрового изображения и проведена оценка его эффективности, согласно которой количество ошибок 1 рода составляет $3,8 \%$, ошибки 2 рода - 9,8\%. Перспективы дальнейшего развития данной работы заключаются в совершенствовании выявления различных способов искусственного повышения резкости цифрового изображения.

Ключевые слова: выявление повышения резкости, цифровое изображение, нарушения целостности, защита информации, фильтр «unsharp mask», коэффициент резкости, пик гистограммы, цифровые компоненты 